Ritrýnd grein birt 31. desember 2020

\title{
Sýn barna á kórónuveiruna og áhrif hennar á pátttöku peirra í daglegu starfi í leikskóla
}

\author{
Sara M. Ólafsdóttir, Kristín Karlsdóttir og Díana L. Sigurjónsdóttir \\ Abstract Um höfunda About the authors $>$ Heimildir
}

Markmið pessarar rannsóknar var að komast að hvernig börn upplifðu leikskólastarf á tímum COVID-19 pegar fyrsta bylgja faraldursins gekk yfir. Tilgangur rannsóknarinnar var að læra af börnunum og nýta pá pekkingu sem skapaðist til pess að styðja betur við börn á fordæmalausum tímum. Rannsóknin byggir á peim hugmyndum að börn á leikskólaaldri séu getumiklir einstaklingar sem byggi upp pekkingu í samvinnu við önnur börn og fullorðna, pau hafi rétt til pess að hafa áhrif og vera gerendur í eigin lífi. Pátttakendur í rannsókninni voru 23 börn, 3-6 ára, á premur deildum í einum leikskóla á landsbyggðinni. Tekin voru hópviðtöl við börnin og peim boðið að teikna á meðan pau ræddu við rannsakanda. Helstu niðurstöður eru að börnin sýndu töluverða pekkingu á kórónuveirunni og peim áhrifum sem hún hafði á daglegt starf í leikskólanum. Börnin höfðu mismunandi sýn á pær takmarkanir sem settar voru vegna sóttvarna, sumum fannst gott að hafa fá börn í leikskólanum en önnur upplifðu sig ein í barnahópnum vegna fjarveru vina og vildu ekki leika sér. Börnin töluðu um efnivið og svæði í leikskólanum sem peim pótti skemmtilegast að leika sér á en pau höfðu ekki aðgang að vegna takmarkana og pað pótti peim leiðinlegt. Niðurstöðurnar undirstrika mikilvægi pess að taka parf mið af sjónarmiðum barna og hlusta á fjölbreytta tjáningu peirra svo að styðja megi betur við parfir peirra og velliððan í daglegu starfi leikskólans á tímum takmarkana sem og aðra daga.

Efnisorð: Sjónarmið barna, áhrifamáttur barna, leikskóli, daglegt starf, kórónuveiran

\section{Inngangur}

Nú eru fordæmalausir tímar par sem heimsfaraldur geisar og hefur áhrif á samfélagið í heild sinni - par á meðal skólakerfið. Hann stafar af COVID-19 sem er afbrigði af kórónuveiru en bæði pessi heiti verða notuð í umfjölluninni um faraldurinn í pessari rannsókn. Gripið hefur verið til mismunandi aðgerða víða um heim en í mörgum löndum var leik- og grunnskólum lokað til pess að hægja á smiti og hlífa heilbrigðiskerfinu. Pessar lokanir höfðu áhrif á menntun $80 \%$ barna í heiminum (Lancker og Parolin, 2020). Lancker og Parolin (2020) rannsökuðu hvaða áhrif lokanir skóla höfðu á félagsstöðu og heilsufar barna sem lifa í fátækt. Niðurstöður sýndu að fæðuöryggi pessara barna minnkaði auk pess sem peim fór meira aftur í námi en börnum sem áttu efnaða foreldra. Niðurstöðurnar gefa til kynna að lokanirnar geti haft langvarandi áhrif á heilsu, vellíðan og námsárangur pessara barna (Lancker og Parolin, 2020; Lee og Raszka, 2020). Í ljósi pessa má gera pví skóna að ábyrgð leikskólakennara og annars starfsfólks sé mikil hvað varðar að styðja við og styrkja börn, ekki síður pau sem koma frá fjölskyldum sem eru í félagslega erfiðri stöðu, hvort heldur sem er vegna fátæktar eða annarra félagslega erfiðra aðstæðna. Niðurstöður nýlegrar rannsóknar (Pascal, Bertram, Cullinane og Holt-White, 2020), styðja petta en ítreka mikilvægi pess að börn geti átt í samskiptum við jafnaldra sína, ekki síst pau sem eru í viðkvæmri stöðu. Rannsakendurnir telja að í 
leikskólum geti börn jafnframt purft að upplifa minni aðgang að áhugaverðum leik og verkefnum eða jafnvel orðið af útivist og hreyfingu vegna breytinga á skipulagi og framkvæmd sóttvarna. Í rannsókn Lees og Raszkas (2020) kemur fram að börn smitist sî̉ur en fullorðnir af kórónuveirunni sem veldur COVID-19-sjúkdómnum, veikist minna og par af leiðandi smiti pau síður aðra. Peir töldu pessa vitneskju vera mikilvæga pegar teknar væru ákvarðanir um fyrirkomulag skólahalds.

Hér á landi var tekin sú ákvörðun að loka ekki leik- og grunnskólum en í stað pess voru settar ákveðnar takmarkanir á skólahald. Pað var gert svo hægt væri að halda leikskólastarfinu gangandi en á sama tíma að fækka smitleiðum. Pann 13. mars 2020 sendi heilbrigðisráðuneytið út auglýsingu um takmörkun á skólastarfi vegna farsóttar (nr. 216/2020). Í 3. grein kom fram að leikskólum væri heimilt að starfa áfram gegn peim skilyrðum að barnahóparnir væru eins fámennir og mögulegt væri og einnig pyrftu peir að vera aðskildir. Hvert sveitarfélag gat útfært pessar breytingar eftir aðstæðum hverju sinni, svo sem stærð leikskóla, rými, staðsetningu, fjölda barna og starfsfólks. Pví var misjafnt eftir sveitarfélögum hvernig útfærslunni á pessum takmörkunum var háttað en pær stóðu yfir í sjö vikur, eða til 4. maí. Algengt var að barnahópnum væri skipt í tvennt pannig að helmingur barnanna mátti mæta í einu en auk pess voru foreldrar hvattir til pess að hafa börnin heima ef peir hefðu tök á pví. Pví má reikna með að pessar takmarkanir hafi haft töluverð áhrif á leikskólastarfið, starfsfólkið, börnin og fjölskyldur peirra.

Markmið rannsóknarinnar, sem fjallað er um í pessari grein, var að komast að pví hvernig börnin sjálf upplifðu petta breytta leikskólastarf á tímum COVID-19. Tilgangur rannsóknarinnar var að læra af börnunum og nýta pá pekkingu sem skapaðist til pess að styðja betur við börn á fordæmalausum tímum. Mikilvægt er að hafa í huga að börn hafa oft aðra sýn, reynslu og upplifun af aðstæðum sínum en fullorðnir og pví er mikilvægt að raddir peirra komi einnig fram (Jóhanna Einarsdóttir, 2012). Börn hafa rétt til pess að tjá sig og hafa áhrif á eigið líf (lög um samning Sameinuðu pjóðanna um réttindi barnsins nr. 19/2013) og pví ber fullorðnum skylda til pess að bjóða börnum til pátttöku í umræðu um mikilvæg málefni sem snerta pau og peirra líf. Rannsóknin er styrkt af Nýsköpunarsjóði námsmanna, styrknúmer 207378-0091.

\section{Áhrifamáttur barna ${ }^{1}$}

Í pessari rannsókn er litið svo á að nám barna fari fram í gagnvirkum samskiptum barna og félagslegs umhverfis peirra. Auk pess er samkvæmt pessum hugmyndum litið á börn á leikskólaaldri sem getumikla einstaklinga sem byggja upp pekkingu í samvinnu við önnur börn og fullorðna. Jafnframt er lögð áhersla á rétt barna til að hafa áhrif og að vera gerendur í eigin lífi; nota áhrifamátt (e. agency) sinn (Mayall, 2003; Prout og James, 2015). Í ljósi pessa er réttur barna til að stunda nám og fá pá umönnun sem pau parfnast virtur en einnig réttur peirra til að á pau sé hlustað og pau studd til að hafa áhrif á sitt nánasta umhverfi, sem fullgildir pegnar samfélagsins. Á sama tíma er litið á börn sem valdalítinn hóp, sem er háður fullorðnum og jafnvel sé hætt við að fullorðnir, sem hafa meira vald en pau, beiti pau kúgun eða pvingunum (Mayall, 2003; Prout og James, 2015). Hlutverk fullorðinna í lífi barna er pví að hluta til mótsagnakennt par sem pað felst annars vegar í að vernda pau og hins vegar að styðja pau til áhrifa í eigin lífi (Alderson, 2008; lög um Samning Sameinuðu pjóðanna um réttindi barnsins nr. 19/2013). Samkvæmt ofangreindum hugmyndum um nám er pví nauðsynlegt í leikskólastarfi að leikskólakennarar jafnt sem leiðbeinendur leiti valdajafnvægis milli fullorðinna og barna (Bae, 2009; Bernstein, 2000). Petta getur átt við í námsaðstæðum par sem leikur er virtur, viðfangsefni er á forsendum barna og frumkvæði peirra fær notið sín.

Leikskólastarf sem tekur mið af að stutt sé við áhrifamátt barna birtist m.a. í að börn séu viðurkennd og virt fyrir hver pau eru og metin af styrkleikum sínum. Hugtökin áhrifamáttur (e. agency), fullgildi (e. belonging) og vellíðan (e. well-being) barna tengjast og vísa til pess að barnið upplifi að pað sé pátttakandi í hóp eða samfélagi. Pau fjalla um að hvaða marki barninu líður vel í eigin skinni og

Á íslensku hafa verið notaðar tvær aðrar pýðingar á ,,agency“; atbeini og gerendahæfni. Hugtakið hefur mismunandi merkingu eftir bví félagslega samhengi og peirri sýn sem byggt er á hverju sinni. pessi rannsókn leggur til grundvallar hugmyndir um að börn séu í senn getumikil (Prout og James, 2015) og hafi rétt til að hafa áhrif í eigin lífi (lög um samning Sameinuðu pjóðanna um réttindi barnsins, nr. 19/2013). Dví er hér stuðst við býðingu á orðinu ,agency“ sem leggur sérstaka áherslu á áhrif barna. 
upplifir andrúmsloft par sem pað getur notið pess að fylgja hugdettum sínum og tilgátum. Pannig er gert ráð fyrir að grunnpörfum barna geti verið fullnægt, auk parfarinnar fyrir athygli, ástúð og viðurkenningu sem getur leitt til pess að peim finnist pau vera hæfir einstaklingar (Carr og Lee, 2019; Laevers, 1994). Með pví móti má segja að í leikskólum finni börn fyrir öryggi ef pau geti treyst leikskólakennurum og öðru starfsfólki, sem m.a. birtist í hvort börnin upplifi að á pau sé hlustað, óskað sé eftir peirra viðhorfum og tekið sé mið af sjónarmiðum peirra við ákvarðanatöku (Byrne og Lundy, 2019; Lansdown, 2005). Jafnframt hafa rannsóknir sýnt fram á að tengsl eru milli vellíðanar ungra barna og pess að pau hafi áhrif í sínu nánasta umhverfi. Fram hefur komið að pegar börn finna fyrir áhrifamætti sínum finni pau sig jafnframt örugg í skólasamfélaginu (Moore og McArthur, 2017; Steckermeier, 2019). Pví má undirstrika mikilvægi pess að börn séu upplýst um aðstæður og pegar parf að endurskipuleggja og finna aðrar leiðir í leikskólastarfinu sé peim gert kleift að tjá skoðanir sínar og taka pátt í að finna lausnir.

Á undanförnum áratugum hefur aukin áhersla verið á að fá fram sjónarmið barna, bæði í rannsóknum og í leikskólastarfi (Dockett, Einarsdóttir og Perry, 2012; Groundwater-Smith, Dockett og Bottrell, 2015). Petta er í samræmi við markmið rannsóknarinnar sem hér er kynnt en par er sjónum beint að sjónarmiðum barna gagnvart daglegu starfi í leikskóla par sem pau eru pátttakendur í samfélagi par sem kórónuveiran hefur geisað.

\section{Daglegt starf og pátttaka barna í leikskóla}

Í pessari rannsókn er fjallað um viðfangsefni sem er nýtt af nálinni og pví ekki auðvelt að finna fyrri rannsóknir til pess að byggja á. Pví var valið að fjalla um pá pætti sem teljast mikilvægir fyrir gæðastarf í leikskólum. Samkvæmt Aðalnámskrá leikskóla 2011 (Mennta- og menningarmálaráduneytið, 2011) er gert ráð fyrir að nám barna fari fram með pátttöku peirra í daglegum athöfnum í leikskólanum í gegnum leik og önnur skapandi viðfangsefni. Áhersla er lögð á að menntun barna felist í að styðja við styrkleika og hæfni peirra en jafnframt eigi að efla skilning peirra á eigin styrkleikum og hæfni, m.a. með að hvetja börn til pess að finna lausnir á margvíslegum málum í margræðu og flóknu samfélagi. Sömuleiðis er lagt til að í skólasamfélagi sé börnum gert kleift að tjá parfir sínar og áhuga, að á pau sé hlustað og pannig séu pau studd til áhrifa í samfélaginu. Bjóða á börnum upp á fjölbreytt námsumhverfi par sem pau fá tækifæri til að taka eigin ákvarðanir og njóta styrkleika sinna, sem er lykilpáttur í að byggja upp jákvæða sjálfsmynd barna (Mennta- og menningarmálaráðuneytið, 2011).

Leikskólastarf er um margt fjölbreytt og jafnframt flókið og pað má einnig segja um pátttöku barna í leikskólastarfi. Litið er svo á að með pátttöku (e. participation) í leikskólasamfélagi (Rogoff, 2003) kynnist börn venjum og hefðum með pví að fylgjast með og taka pátt í pví sem fram fer í samfélaginu. Rogoff lýsir pessari pátttöku nánar með hugtakinu pátttökuleiðsögn (e. guided participation) sem vísar til leitar barna og fullorðinna að skilningi á sjónarmiðum hvers annars, par sem pau í samvinnu styðja við pátttöku hvers annars og deila með sér reynslu og upplifun. Pví má líta svo á að pátttökuleiðsögn feli ekki eingöngu í sér samskipti sem ætlað er að kenna barni/börnum tiltekna pekkingu heldur einnig að barnið/börnin verði smám saman hluti af samfélaginu og taki pátt í að móta menningu leikskólans (Rogoff, 2003; Rogoff, Moore, Correa-Chávez og Dexter, 2014). Í gagnvirkum samskiptum barna í sínu nánasta umhverfi móta pau hugmyndir sínar og tilgátur og um leið skilning sinn á umheiminum. Í pessum skilningi er pví ekki litið eingöngu á nám barna sem ferli heldur er einnig litið svo á að nánasta umhverfi barnanna, leikskólakennarar og foreldrar hafi áhrif á nám peirra.

Leikskólakennarar og leiðbeinendur eru lykilpersónur í að skapa aðstæður í leikskólum par sem börnum er boðið upp á námstækifæri sem byggja á áhuga peirra og virkni (Carr og Lee, 2019). Hlutverk leikskólakennara og annars starfsfólks er pví að eiga í samskiptum við börn, örva pau og styðja við samskipti peirra í leik og pátttöku í öðrum viðfangsefnum (Karlsson Lohmander og Pramling Samuelsson, 2015; Wood, 2014). Í leikskólastarfi er pví mikilvægt að tekið sé mið af sjónarmiðum barna. Rannsóknir sem gerðar hafa verið út frá sjónarmiðum barna hafa sýnt að vinátta og leikur séu pættir sem börnum pykir einna mikilvægastir í daglegu starfi leikskólans. Peim lídi vel 
í leikskólanum pegar pau geti leikið við vini sína og finnist pau tilheyra barnahópnum (Jóhanna Einarsdóttir og Sara M. Ólafsdóttir, 2020). Auk pess sé virk pátttaka peirra í daglegu starfi mikilvæg par sem pau hafi val um leikfélaga, fjölbreyttan efnivið og leiksvæði (Sara M. Ólafsdóttir og Bryndís Garðarsdóttir, 2016).

Fyrstu niðurstöður úr rannsóknum á tímum COVID-19 hafa verið að birtast en pær Ingibjörg Ósk SigurðardóttirogSvavaBjörgMörk (2020)kynntu, ámálpingimennta-ogmenningarmálaráðuneytisins pann 10. september 2020, fyrstu niðurstöður um áhrif fækkunar í barnahópi á leik barna á tímum COVID-19 út frá sjónarmiði leikskólastjórnenda og leikskólakennara. Niðurstöðurnar sýndu að í flestum leikskólum voru barnahóparnir fámennari en venjulega og hafði pað jákvæð áhrif á leik barna. Leikskólakennararnir sem rætt var við töldu að leikur barnanna hefði verið dýpri og börnin fengið meiri tíma til pess að próa hann. Andrúmsloftið hefði verið rólegra í leikskólanum, árekstrum milli barna hefði fækkað og mörg barnanna blómstrað í leik og starfi. Færri börn í hóp hefði leitt til aukinnar vellíðanar barnanna í leikskólanum. Pó komu einnig fram neikvæð áhrif en algengt var að barnahópnum var skipt í tvennt sem leiddi til pess börn gátu stundum ekki verið með vinum sínum og söknuðu peirra.

Hér verður fjallað um sjónarmið barna gagnvart daglegu starfi í leikskóla par sem breyttar áherslur voru vegna takmarkana á skólahaldi. Rannsóknarspurningin var:

Hvernig upplifa leikskólabörn kórónuveiruna og áhrifhennar á pátttöku peirra i daglegu starfi leikskólans?

\section{Pátttakendur og vettvangur}

Rannsóknin var framkvæmd í einum leikskóla á landsbyggðinni. Leikskólinn er sex deilda og par dvelja að jafnaði um 120 börn samtímis. Pátttakendur voru 23 börn á aldrinum 3-6 ára en pau voru á premur eldri deildum leikskólans. Alls 11 börn voru fædd árið 2014, 9 börn fædd 2015 og 3 börn fædd 2016. Pátttaka barnanna var breytileg vegna pess að börnunum var skipt í hópa og mættu ekki alla daga í leikskólann. Deildarstjórar deildanna buðu peim börnum sem mætt voru pá daga sem rannsóknin fór fram að taka pátt. Rannsakandinn sem fór á vettvang og sá um leyfisvinnunna og gagnaöflunina er priðji höfundur pessarar greinar. Hann pekkti vel til leikskólans, umhverfisins, pátttakendanna og starfsfólksins.

Venjulega var skipulag leikskólans nokkuð sveigjanlegt par sem börnin gátu oft valið sér leikfélaga, viðfangsefni og leiksvæði. Lögð var áhersla á leik barna og fjölbreytt viðfangsefni. Hver deild var með ákveðinn efnivið til leiks en börnin máttu fara á milli deilda og fá lánað ef pau vantaði efnivið í leik sinn. Börnunum var einnig skipt í minni hópa pegar farið var í hópastarf, sal eða listasmiðju. Foreldrar og aðrir ættingjar voru velkomnir inn á deildir pegar peir komu með börnin í leikskólann á morgnana eða sóttu pau í lok dags. Börnin höfðu aðgang að bókasafni og spilasafni sem staðsett var í sameiginlegu rými leikskólans. Börnin fóru í útiveru einu sinni til tvisvar á dag, í eina til eina og hálfa klukkustund í senn. Heildarfjöldi barna og starfsmanna var mismunandi á milli deilda en var að meðaltali um 19-20 börn og 5-6 starfsmenn á deild, par sem vinnutími peirra var breytilegur.

Pegar takmarkanir vegna sóttvarna voru settar á var leikskólanum skipt niður í fjögur sóttvarnahólf og enginn mátti fara á milli hólfanna nema leikskólastjórinn. Hámarksfjöldi barna á deildum var 12 en með peim voru 3-4 starfsmenn. Lögð var áhersla á að börn sem áttu forgang eða voru í viðkvæmri stöðu fengju að mæta í leikskólann, einnig börn sem áttu foreldra í framlínustörfum. Afleiðing pessa var sú að sum barnanna gátu einungis mætt einu sinni til tvisvar í viku. Börnin máttu aðeins vera inni á sinni deild og öll sameiginleg rými voru lokuð, svo sem salur og listasmiðja. Pau máttu ekki fara um skólann eins og áður hafði verið. Leikefni var takmarkað, ekki var unnt að bjóða upp á leikefni sem erfitt var að sótthreinsa, svo sem perlur, leir, einingakubba, bækur og púsl. Pó voru í boði harðspjaldabækur og trépúsl. Börnin í hverju sóttvarnahólfi fóru í útiveru einu sinni á dag, klukkutíma í senn. Foreldrar barnanna máttu hvorki koma inn á deildir né ganga í gegnum leikskólabygginguna. Samskipti við foreldra urðu oftar á rafrænu formi; til dæmis var tölvupósturinn meira notaður en áður. 


\section{Аðferðafræði og aðferð}

Í pessari rannsókn var stuðst við eigindlega aðferðafræði par sem leitað var eftir að fá fram upplifanir barnanna, reynslu peirra, skoðanir, hugmyndir og viðhorf gagnvart daglegu starfi í leikskólanum pegar takmarkanir voru vegna kórónuveirunnar. Âkveðið var að taka rýnihópaviðtöl við börnin og bjóða peim að teikna á meðan pau töluðu við rannsakanda. Tilgangur pess var að nýta mismunandi rannsóknaraðferðir með börnunum pannig að pau gætu tjáð sig með mismunandi hætti og með pví móti myndu gögnin varpa betra ljósi á heildarmyndina (Jóhanna Einarsdóttir, 2012). Rannsakandanum pótti einnig mikilvægt að halda rannsóknardagbók í gegnum allt ferlið par sem hann hélt utan um hvað var að gerast hverju sinni og hvernig pað gekk - auk pess að skrá ýmis huglæg atriði og ígrundun á pví sem átti sér stað í rannsóknarferlinu.

Ástæðan fyrir að viðtölin voru tekin við börnin í hóp en ekki sem einstaklingsviðtöl var sú að börnin fengu stuðning hvert frá öðru, hjálpuðu hvert öðru og urðu öruggari með pví að vera nokkur saman (MacNaughton, Rolfe og Siraj-Blatchford, 2010). Umræðurnar urðu líflegar pví að pau töluðu saman sín á milli og hjálpuðust að við að svara spurningum. Hópaviðtöl henta einnig vel til pess að koma í veg fyrir valdaójafnvægi á milli rannsakandans og barnanna pví pá eru pau í meirihluta með einum rannsakanda (Jóhanna Einarsdóttir, 2012). Stuðst var við viðtalsramma og pess gætt að hafa flæði í viðtalinu. Meðan á viðtalinu stóð fengu börnin að teikna frjálst og ræddu svo við rannsakanda um teikningar sínar. Teikningar eru góð aðferð til pess að fá fram upplifun og sjónarhorn barnanna. Pær eru sérstaklega hentugar með börnum sem eiga erfitt með að tjá sig með orðum (MacNaughton o.fl., 2010). Par fá börnin líka tækifæri til pess að skapa, nota hugmyndaflugið og tjá sig á sinn hátt, en pó með öðrum hætti en í viðtalinu sjálfu (Jóhanna Einarsdóttir, Dockett og Perry, 2009). Teikningar barnanna gáfu enn frekari innsýn í upplifun peirra til viðbótar peim upplýsingum sem fengust í viðtölunum. Pví má segja að pessar tvær leiðir í gagnaöflun hafi unnið vel saman.

\section{Framkvæmd og gagnaöflun}

Gagnaöflunin fór fram í tveimur hlutum. Fyrri rýnihópaviðtölin voru tekin við börnin í lok apríl á meðan samkomubann og takmarkanir á skólastarfi voru í gildi. Tveimur mánuðum síðar, í lok júní, voru aftur tekin viðtöl við sömu börnin. Í bæði skiptin voru börnin beðin um að teikna mynd út frá umræðunum. Tilgangur pess að taka tvö rýnihópaviðtöl við börnin var að fá fram upplifun peirra bæði meðan á takmörkunum stóð og einnig pegar búið var að létta á peim. Rannsakandi taldi mikilvægt að fá fram sjónarhorn barnanna meðan á takmörkunum stóð vegna pess að börn eiga oft auðveldara með að segja frá pví sem gerist hér og nú í stað pess að muna pað sem áður hafði verið gert.

Vegna aðstæðna var tíminn fyrir gagnaöflun takmarkaður en prátt fyrir pað reyndi rannsakandi eftir bestu getu að hafa í huga hvaða tími hentaði best fyrir hvert og eitt viðtal, bæði pannig að pað truflaði börnin sem minnst sem og leikskólastarfið, en tímasetningin var einnig ákveðin í samráði við deildarstjórana. Viðtölin voru tekin í herbergjum sem voru nálægt deildum barnanna, á svæði sem pau pekktu vel. Pað var gert bæði til pess að samtölin við börnin yrðu hversdagslegri fyrir pau en einnig vegna pess að ekki var heimilt að fara á milli svæða í leikskólanum par sem sett höfðu verið upp sóttvarnahólf til pess að draga úr smithættu vegna COVID-19. Börnin voru ýmist 3 eða 4 í hóp og reynt var að hafa sömu börn í sömu hópum í seinni hluta gagnaöflunarinnar. Tekin voru 7 viðtöl í fyrri hlutanum og 7 í seinni, pau voru pví 14 talsins. Viðtölin tóku allt frá 12 mínútum upp í eina klukkustund en algengasti tímalengdin var í kringum 30 mínútur.

\section{Siðferðileg álitamál}

Áður en gagnaöflun fór fram fékk rannsakandinn öll tilskilin leyfi og sampykki frá hliðvörðum barnanna, par á meðal skólastjóra, deildarstjórum og foreldrum barnanna (Guðrún Kristinsdóttir og Hervör Alma Árnadóttir, 2015). Eftir pað fékk hann upplýst sampykki frá börnunum sjálfum. Rannsakandinn veitti börnunum upplýsingar á einföldu máli og á pann hátt sem pau skildu svo pau gætu tekið upplýsta ákvörðun um pátttöku sína. Pau fengu vitneskju um markmið rannsóknarinnar, 
hvað rannsóknin fæli í sér, hvað mundi gerast og hve lengi. Pau fengu að vita til hvers var ætlast af peim, hvað yrði gert við gögnin og hvernig niðurstöðurnar yrðu notaðar. Pau fengu einnig að vita að pau réðu pví sjálf hvort pau vildu taka pátt eða ekki og að pau hefðu leyfi og vald til pess að draga sig út úr rannsókninni pegar pau vildu. Leitað var eftir sampykki barna í hvert skipti sem viðfangsefni sem tengdust rannsókninni voru lögð fyrir en ekki einungis í upphafi rannsóknarinnar (Dockett o.fl., 2012). Útskýrð voru fyrir peim atriði er varða nafnleynd og í kjölfarið fengu pau að velja sín eigin dulnefni sem notuð voru í úrvinnslu gagnanna. Börnin völdu sér fjölbreytt og frumleg dulnefni eins og sjá má í niðurstöðukafla. Rannsakandinn sagði peim einnig frá pví að ef pau vildu ekki svara einhverjum spurningum, peim fyndust pær ef til vill ópægilegar, pá pyrftu pau ekki að svara; einnig að pau mættu hætta í viðtalinu eða rannsókninni hvenær sem væri án afleiðinga. Rannsakandinn sagði börnunum frá að hann ætlaði að taka viðtalið upp og útskýrði hvers vegna, meðal annars svo að hann gæti hlustað á pað aftur seinna og gleymdi ekki neinu. Pegar búið var að fara yfir öll pessi mikilvægu atriði voru börnin beðin um munnlegt sampykki sitt fyrir pátttöku í rannsókninni og sampykktu pau öll. Taka skal fram að einungis voru 19 pátttakendur af 23 í seinni viðtölunum, tvö börn voru komin í sumarfrí og tvö börn í einum hópnum voru í miðjum leik, pegar rannsakandi bauð peim í seinna viðtalið, og völdu pau að taka ekki pátt.

\section{Gagnagreining}

Viðtölin voru tekin upp sem hljóðskrá og afrituð frá orði til orðs. Teknar voru myndir af teikningunum og pess gætt að pær fylgdu með viðtali við eiganda. Allir prír rannsakendur greindu gögnin fyrst hver í sínu lagi til að fá fram mismunandi sjónarhorn á gögnin og til að auka trúverðugleika rannsóknarinnar (Braun og Clarke, 2013). Rannsakendur vildu láta gögnin tala til sín og voru ekki með nein fyrir fram ákveðin pemu. Peir héldu fundi reglulega til pess að skiptast á skoðunum og hugmyndum og tóku ákvarðanir um framhaldið hverju sinni. Síðan var notuð pemagreining til pess að greina gögnin (Braun og Clarke, 2006, 2013). Pau voru kóðuð en kóðarnir sem fram komu voru meðal annars hugmyndir barnanna, vitneskja peirra, pátttaka og vellíðan. Pessir kóðar voru síðan settir saman í pemu sem greint verður frá í niðurstöðum rannsóknarinnar.

\section{Niðurstöður}

Börnin sem tóku pátt í rannsókninni ræddu um daglegt líf sitt í leikskólanum, bæði meðan á takmörkunum stóð og eftir að peim var aflétt. Hér verður fjallað um niðurstöður rannsóknarinnar út frá samtölunum við börnin og túlkun á teikningum peirra. Dulnefnin sem pau völdu sér eru notuð og rannsakandi er tilgreindur sem R í samtölunum. Í gögnunum komu fram hugmyndir og pekking barnanna á kórónuveirunni, pátttaka barnanna î daglegu starfi og líðan peirra á tímum takmarkana.

\section{Hugmyndir og pekking barnanna á kórónuveirunni}

Börnin höfðu ýmsar hugmyndir um kórónuveiruna og flest töluðu um að peim fyndist hún leiðinleg eins og Elsa sagði: „Kórónuveiran! Hún er ógeðslega leiðinleg.“ Rósu fannst kórónuveiran líka leiðinleg og tengdi pað við umræðu um af hverju færri kennarar voru í leikskólanum en venjulega. Pegar rannsakandi ræddi við Snæ talaði hann um hvernig kórónuveiran hefði borist til landsins og hvernig hún færi á milli staða. Hann sagði: „Af pví pá myndi hún bara [...] fara í kringum Ísland [...] alltaf pegar einhver maður er úti og er lasinn [...] pá myndi hann fara í flugvél ... pá myndi ... pá verður pessi kórónuveira á næsta landi ... pá fer pessi maður aftur á Ísland.“ Hann útskýrði petta svo nánar fyrir rannsakanda:

Pað kom ein padda í leðurblöku ... en ... mannfólkið átti að, sko, borða ..., sko, leðurblökurnar af pví pað er, sko, maturinn stundum peirra ... af pví pá tóku pau eina leðurblöku með pöddunni í ... pá voru pau að borða leðurblökuna og einn maðurinn fékk hana í magann og síðan bara kom hún út ... og pá máttu allir á fyrsta landinu ekkert að hittast ... og síðan bara kom hún eitthvað hingað. 
Pegar rannsakandi hitti börnin í seinna skiptið teiknaði Emma Dís tvær myndir um kórónuveiruna, á meðan hún ræddi við rannsakanda, og tvær aðrar stúlkur teiknuðu myndir um daglegt starf í leikskólanum. Emma Dís útskýrði myndirnar sínar á meðan hún teiknaði og um fyrri myndina sagði hún: „Ég ætla að gera kórónuveiruna stóra ... pví hún er svo stór. Petta er kórónuveirukall og kórónuveirukona. Pau eru glöð pví pau eru að setja kórónuveiruna á alla.“

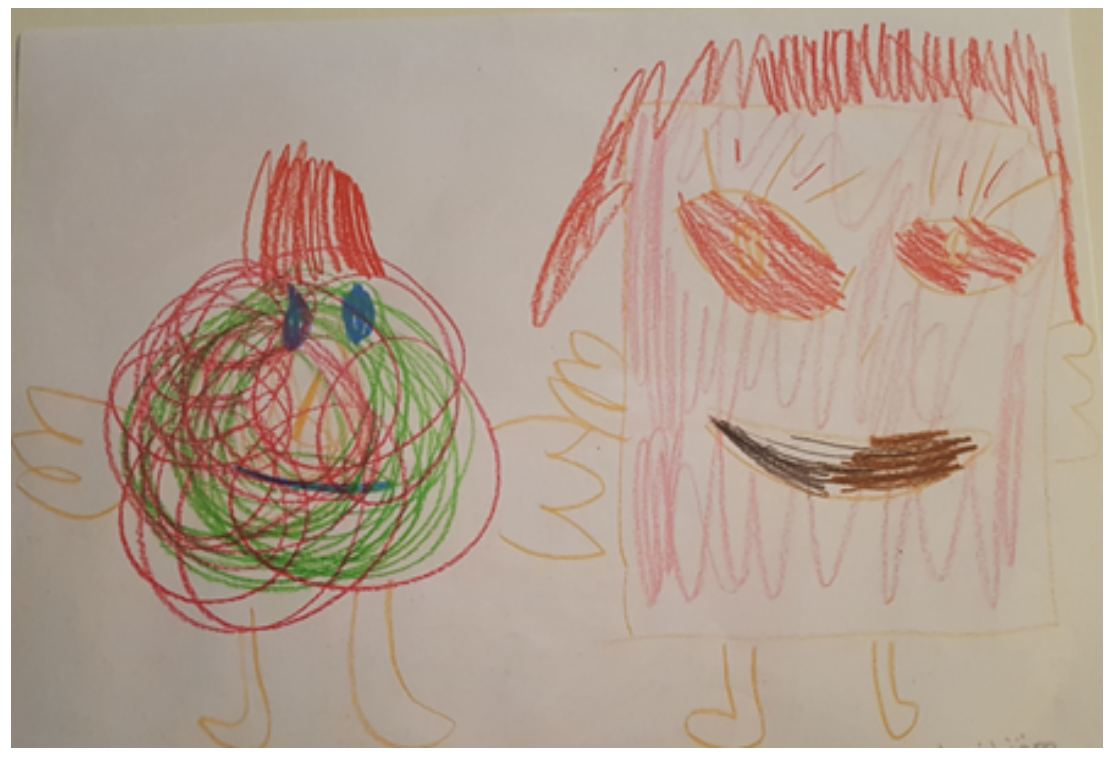

Mynd 1. Kórónuveirukarl og kórónuveirukona (Emma Dís, 26. júní 2020).

Emma Dís fékk svo nýtt blað og hélt áfram að teikna. Eins og hún sagði sjálf frá teiknaði hún græna kórónuveiru og einhyrning með sóttvarnagrímu. Hún sagði svo: „Petta er einhyrningur, bara með grímu fyrir kórónuveirunni. [...] Svo hann fái ekki kórónuveiru í munninn.“

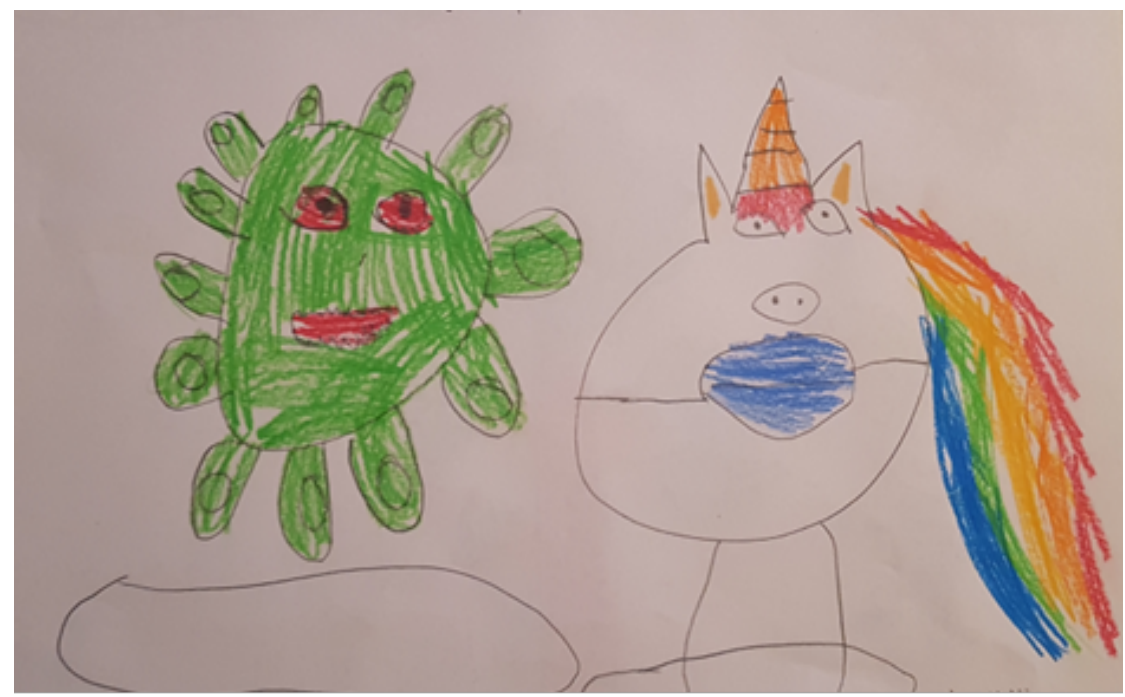

Mynd 2. Græn kórónuveira og einhyrningur með sóttvarnagrímu (Emma Dís, 26. júní 2020).

Regnboga-Birta teiknaði líka mynd á meðan stelpurnar prjár ræddu við rannsakanda. Hér má sjá samtalið sem átti sér stað um myndina sem Regnboga-Birta teiknaði:

Regnboga-Birta: Ég ætla að gera dauðan hér.

Emma Dís: Dauðan einhyrning?

Regnboga-Birta: Já. 
Rósalind: Sumir deyja út af maður er veikur.

R: Já.

Emma Dís: Sumir fá krabbamein.

R: Uhum.

Emma Dís: Sumir deyja út af kórónuveirunni, sumir eru með ofnæmi fyrir henni.

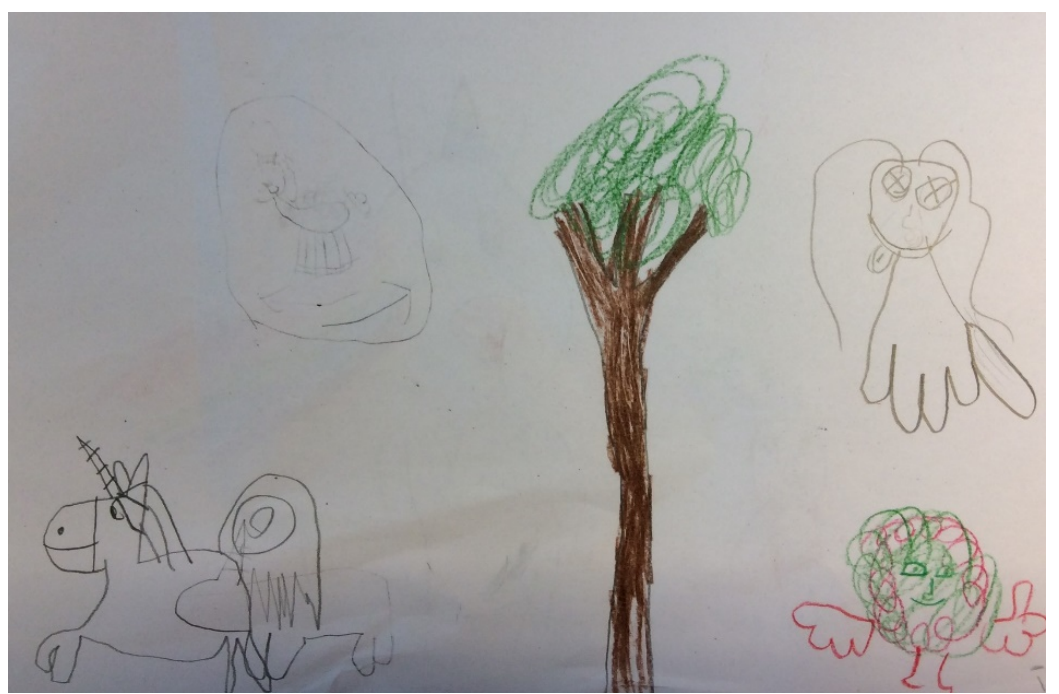

Mynd 3. „Ég ætla að gera dauðan hér.“ (Regnboga-Birta, 26. júní 2020).

Börnin höfðu pví ýmsar hugmyndir um kórónuveiruna og höfðu öðlast pekkingu á pví hvernig og hvaða áhrif hún gæti haft á pau. Áhrifa pess gætti líka í samtali rannsakanda við börnin en í samtali við Rósu klæjaði hana í andlitið og bað um að fá að fara fram í hólfið sitt til pess að ná sér í hanska. Strákur, sem vildi láta kalla sig Blað, spurði pá hvort hann mætti líka fá hanska og pá svaraði Rósa: „Nei, ég er bara með petta til pess að klóra mér.“

\section{Daglegt starf leikskólans á tímum takmarkana}

Pegar börnin ræddu um hvað peim pætti skemmtilegast að gera í leikskólanum töluðu pau oft um að leika við vini sína, leika úti, teikna, mála og fara í heimsókn á aðrar deildir. Mörg barnanna töluðu einnig um að pað væri gaman að vera í salnum. Emma Dís sagði að sér pætti skemmtilegast pegar öll börnin væru saman og Regnboga-Birta tók undir og sagði: „Dað er eiginlega best.“ Rannsakandi spurði stelpurnar hvort pað væri eitthvað öðruvísi î́ leikskólanum og svöruðu pær játandi. Rannsakandi spurði pá: „Hvað er öðruvísi?“ og pær svöruðu:

Emma Dís: Umm ... erum ekki öll saman og ...

Regnboga-Birta: Við erum ekki öll með sama fingrafar.

R: Já.

Rósalind: Pú ert að grípa fram í henni Emmu, ... Regnboga-Birta.

R: Mhm..

Emma Dís: Hérna, ... við erum ekki öll saman og við megum ekki fara í salinn ... og vera hérna að mála ...

R: Okei, ... hvernig finnst ykkur pað? 
Emma Dís: Ekki skemmtilegt.

Rósalind: Ekki skemmtilegt.

Regnboga-Birta: Bara, erum inn á deild að gera ... að reyna að gera eitthvað skemmtilegt

... vera ... stundum erum við að gera pað.

Rósalind, Regnboga-Birta og Emma Dís töluðu auk pess um fjölda barna í leikskólanum. Pær sögðu að krakkarnir væru ekki allir í leikskólanum, t.d. væri Róbert ekki alla daga, bara suma. RegnbogaBirtu fannst leiðinlegt pegar krakkarnir voru ekki allir í einu og sagði:

Pví mig langar alltaf að hitta krakkana á sama tíma. Mig langar eiginlega að kórónuveiran fari bara ... bara öll veikindin. Ef ég væri með fjögurra-laufa-blað pá myndi ég óska pess að öll veikindin myndu fara [...]. Út af pað væri svo gott, pá væri enginn aftur lasinn.

Börnin gerðu sér flest grein fyrir pví af hverju færri börn og kennarar væru í leikskólanum. Litli Nemó orðaði pað pannig: „Út af pessari veikju ... fáránlegu veikju.“ Litli Nemó sagði að hann hataði pessa veikju og fyndist leiðinlegt að pað vantaði börn í leikskólann. Snær, Hreindýr og Rósa ræddu sín á milli og við rannsakanda hvað peim fyndist um að ekki væru allir í leikskólanum. Pau voru sammála um að pað væri ekki skemmtilegt. Guðrún og Kisa ræddu líka ástæðu pess að fá væru börn í leikskólanum og voru sammála um að pað væri vegna pess að fólk gæti smitast. Kisa sagði svo: „Pá getur einhver verið í kremju ef pað eru svona margir." Láru fannst leiðinlegt að Hanna, besta vinkona hennar, væri aldrei í leikskólanum og pegar rannsakandi spurði hvar hún væri sagðist Lára ekki vita рад.

R: En eru allir krakkarnir í leikskólanum?

Lára: Umm, nei.

Anna: Nei, ekki allir.

Sólveig: Pað eru, sko, margir, margir, margir krakkar hjá okkur.

R: Já, en af hverju eru ekki allir í leikskólanum?

Anna: Út af pví að ... kórónuveiran.

Sólveig: Margir geta smitast.

R: Já, hvað finnst ykkur um pað?

Sólveig: Ekki vel. Ég vil bara vera heima alla daga ... og hanga par ... til pess að bíða eftir að pessi kórónuveira hættir bara.

R: Já.

Sólveig: Hún gerir pað ekkert ... hún er enn pá.

R: Er hún enn pá?

Sólveig: Já, pað má ekki lengur vera hlið við hlið og eitthvað svona nálægt ... og leiðast í hendur.

Börnin töluðu einnig um að pað væri ekkert hópastarf eins og pau Kisa, Guðrún og Fiskur bentu á. Pað væru engir hópar af pví að búið væri að breyta út af kórónuveirunni. Pau höfðu misjafnar skoðanir á hvað peim fyndist um pað. Kisa sagði að pað væri skrýtið, Guðrún sagði að sér fyndist pað ekki gaman og Fiskur sagði að pað væri gaman. Pegar rannsakandi spurði pau hvort eitthvað væri öðruvísi i leikskólanum svaraði Fiskur: „Maður má ekki hafa kórónu inni [...] afmæliskórónu.“ Sumir söknuðu pess að hafa hópana eins og peir voru. Litli Nemó vildi hafa pá eins peir voru venjulega. Lára sagði: „Að allir líða vel ... og allir mála ... líka Hanna.“ Guli Hulk sagði: „Ég myndi vilja hafa alla 
saman." Rósa og Blað voru ósammála pví og sögðust ekki vilja hafa alla saman af pví að pá væru svo mikil öskur og læti.

Rannsakandi spurði Erik, Elísabetu og Jarðarber af hverju svona fáir krakkar væru í leikskólanum. Erik svaraði: „Út af veikinni“ og Elísabet bætti við: „... og pað má ekki koma alltof margir inn“ og benti jafnframt á að systir hennar væri heima af pví að pað mættu ekki koma fleiri í leikskólann. Pegar rannsakandi ræddi við Rósu og Snæ par sem pau sátu og teiknuðu kom fram að peim pótti ástandið leiðinlegt. Rósa sagði að sér pætti leiðinlegt að veiran væri í gangi og Snær tók undir pað með henni. Hann bætti við að hann gæti ekki hitt Ólaf, vin sinn, sem væri heima. Hann sagði: „En nú er Ólafur heima ... en ég er bara einn með hinum krökkunum, pá verð ég stundum leiður.“ Rannsakandi sagði pá: „Já, verðurðu leiður?" og Snær svaraði: „Já, af pví að ég get ekki leikið við vin minn.“ Snær teiknaði mynd og lýsti henni fyrir rannsakanda með pessum orðum: „Petta er hann Ólafur glaður heima og petta erum við sem erum að gera verkefnið og pá finnst mér ekkert gaman pví Ólafur er ekki með.“

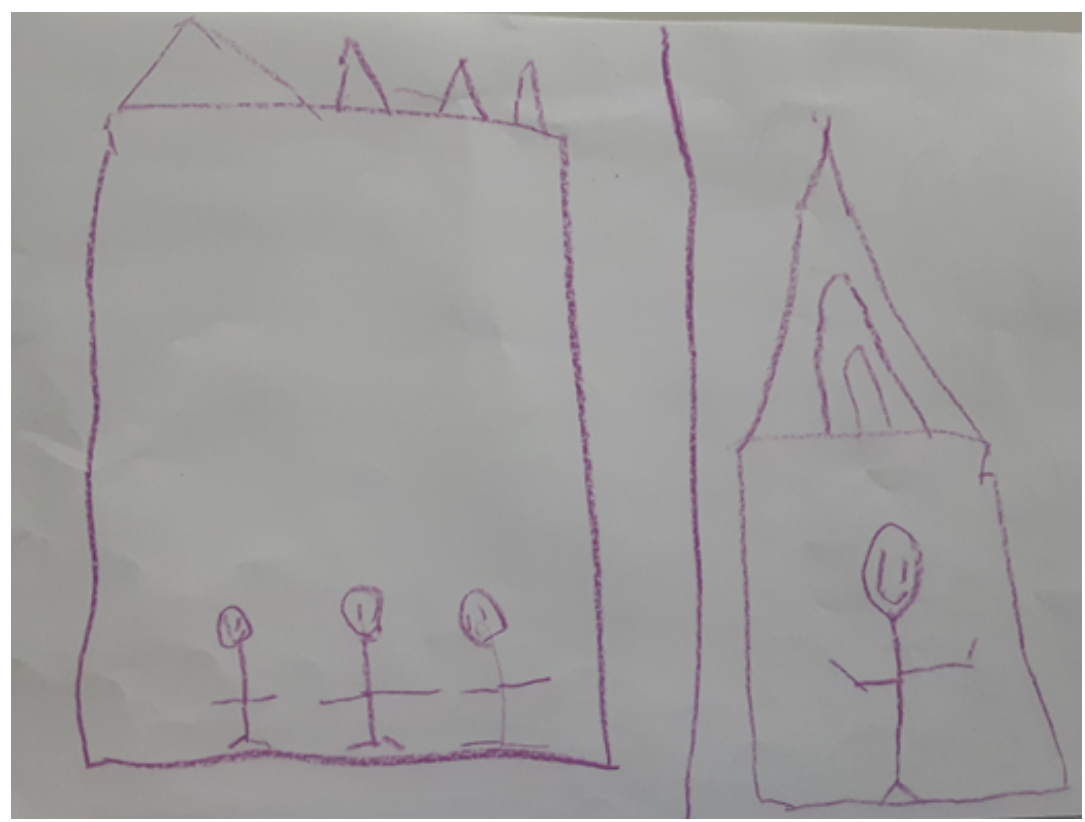

Mynd 4. Ólafur glaður heima og Snær leiður í leikskólanum (Snær, 29. apríl 2020).

Sum barnanna veltu fyrir sér hvar kennararnir sem ekki mættu í leikskólann væru. Sólveig, Lára og Anna nefndu tvo kennara sem ekki mættu í leikskólann og ræddu sín á milli og við rannsakanda hvar peir gætu verið:

Sólveig: Kannski er hún bara búin að smitast.

Lára: Kannski er hún bara í fríi.

Anna: Kannski, ... kannski er einhver, ... kannski er einhver búinn að hnerra á hana.

Lára: Kannski er einhver búinn að stela henni.

R: Já.

Anna: Stundum ... stundum er búið ... stundum er búið að stela manni og stundum er búið að vera veikur ... stundum smitar maður ... stundum hnerrar maður á hvort annað ... ef maður gerir mynd ... og kannski, ef maður er að gera mynd, pá smitar einhver óvart myndina sína ... og einhver segir: Hey hver var að smita myndina mína?

R: Mmm ... já ... 
Anna: Og stundum segir einhver „Ég var að smita myndina pína óvart, ég er með kvef.“

R: Og getur maður pá smitast?

Anna [talar rámri röddu]: Nee, jább ... pá smitar maður alla.

Börnin voru ekki upplýst um hvar kennararnir voru sem ekki gátu mætt til vinnu en notuðu hugmyndaflugið til pess að velta vöngum yfir pví. Börnin voru sammála um að pað væri skemmtilegast að leika við vini sína og taka pátt í fjölbreyttu starfi leikskólans. Pau fundu fyrir töluverðum áhrifum kórónuveirunnar á starf leikskólans og á tengsl sín við önnur börn og fullorðna.

\section{Upplifun barnanna eftir að takmörkunum var aflétt}

Seinni viðtölin voru tekin pegar búið var að létta á takmörkunum. Rannsakandi rifjaði upp með börnunum hvernig hefði verið pegar takmarkanirnar voru vegna kórónuveirunnar og hvernig væri núna. Rannsakandi talaði við Guðrúnu, Fisk og Kisu á meðan pau teiknuðu. Pegar Fiskur var spurður hvernig hefði verið í leikskólanum pegar kórónuveiran var sagði hann að honum hefði pótt pað leiðinlegt vegna pess að hann mátti hvorki leira né smíða. Mörg barnanna sögðu að peim hefði ekki liðið vel á meðan kórónuveiran var. Kisa sagði: „Af pví ég fékk ekki að leira og snerta andlitið.“ Fiskur tók undir með henni og sagði: „Ég fékk ekki heldur að gera pað ... enginn fékk að gera pað.“ Guðrún sagði að pað væri breytt, í dag mætti snerta á sér andlitið og Kisa bætti við: „Af pví að kórónuveiran er alveg að fara." Börnin voru pá spurð hvernig peim liði með pað og pau svöruðu öll að pau væru ánægð með pað.

Rannsakandi rifjaði einnig upp með Emmu Dís, Rósalind og Regnboga-Birtu hvernig hefði verið meðan kórónuveiran var. Emma Dís sagðist bara hafa fengið að vera í leikskólanum svona einu sinni í viku og Rósalind sagði pað líka. Pegar pær voru spurðar hvort eitthvað hefði breyst sögðu pær að núna mættu pær alltaf í leikskólann. Regnboga-Birta bætti við: „Kennararnir mæta alltaf, pað er svolítið seint pegar pað var kórónuveiran en nú mæta peir á réttum tíma." Stelpurnar prjár voru allar sammála um að peim hefði liðið illa pegar kórónuveiran var og pær ræddu petta áfram við rannsakanda:

Regnboga-Birta: Pví pá var ég svolítið hrædd pví mér finnst kórónuveiran eitthvað svo hræðileg.

R: Já.

Emma Dís: Mér fannst eins og að pað væri bara einhver skessa ... að drepa ... pví hún getur drepið einhvern.

R: Að hún væri $\ldots$ að hún væri eins og skessa?

Emma Dís [Kinkar kolli].

R: Uhum.

Regnboga-Birta: Mér finnst ... ég hugsa eiginlega eitthvað svona mikið um kórónuveiruna.

Samtalið við stelpurnar hélt áfram og rannsakandi sagði: „En nú eruð pið búnar að segja mér svolítið hvernig ykkur fannst í leikskólanum pegar kórónuveiran var ..." Pá sagði Emma Dís: „Sem er enn pá“ og benti á að veiran væri ekki farin. Rannsakandi spurði pá: „En hvernig líður ykkur núna?“ Emma Dís svaraði: „Illa ... af pví hún er enn pá.“ Regnboga-Birta bætti við: „Mér líður svolítið skringilega en eiginlega líður mér bara vel pví ég gleymi alltaf kórónuveirunni." Rósalind tók undir með Regnboga-Birtu og sagði: „Pegar ég hugsa um kórónuveiruna reyni ég bara að gleyma henni.“ Rannsakandi spurði pá um hvað hún hugsaði í staðinn og pá sagði Regnboga-Birta: „Bara um eitthvað fallegt örugglega.“ 
Í samtali við Erik kom fram að honum hefði ekki pótt skemmtilegt pegar kórónuveiran var og sagði: „Pá fórum við ekkert út ... fengum ekki að velja neitt eða lita eða perla ... eða fara út að leika." Hann bætti svo við: „Enginn gerði neitt skemmtilegt ... við fengum ekki að lesa.“ Pegar hann var spurður hvernig honum liði núna sagði hann: „Vel ... a a pví að núna erum við að gera allt skemmtilegt.“ Elísabetu fannst gaman að purfa ekki að fara í leikskólann pegar kórónuveiran var. Hún sagði: „Ég mátti vera heima og heima hjá ömmu minni ... pað var skemmtilegt." Hún talaði um að sér liði ekki vel í leikskólanum núna pegar allir væru komnir aftur. Pegar rannsakandi spurði: „Hvernig finnst ykkur að hafa alla krakkana?“ svaraði hún: „Ekki vel ... ekki vel, pá eru allir að öskra.“

Rannsakandi spurði pær Sólveigu, Rósu og Láru hvort peim fyndist eitthvað leiðinlegt eða erfitt í leikskólanum. Láru fannst erfiðast að teikna einhyrning og leiðinlegast að fara á klósettið. Rósa og Lára töluðu um að pær myndu vel eftir takmörkunum sem hefðu verið í leikskólanum og pær töluðu um að pá hefði peim fundist leiðinlegast að mega ekki fara í salinn. Pær langaði til pess en sögðu að pað mætti ekki út af COVID-19. Lára taldi að veiran væri farin en Rósa sagði: „Ekki alveg ... pað er komið aftur.“ Lára bætti pá við „Kórónuveiran er bráðum að fara, mamma sagði pað.“

\section{Umræða}

Hér hefur verið greint frá rannsókn með börnum um upplifun peirra af peim takmörkunum sem settar voru á tímum heimsfaraldurs COVID-19. Niðurstöðurnar eiga einungis við um börnin sem tóku pátt, í peim aðstæðum sem pau voru hluti af og á peim tíma sem rannsóknin fór fram en mikilvægt er að draga lærdóm af sjónarmiðum peirra. Fram kom að börnin höfðu mismunandi sýn á aðstæður sínar og vellíðan í leikskólanum meðan á pessu stóð. Á tímum COVID-19 mátti ekki fara á milli sóttvarnahólfa, pví voru svæði utan deildarinnar ekki í notkun og útiveran takmörkuð. Pví pótti áhugavert að heyra að börnin skyldu oftast nefna svæði utan deildarinnar pegar pau töluðu um hvað peim pótti skemmtilegast að gera í leikskólanum, t.d. að fara í salinn, að mála í listasmiðjunni, í heimsókn á aðrar deildir og út að leika. Auk pess var takmarkað aðgengi að leikefni og leiksvæðum og greinilegur söknuður hjá börnunum varðandi pað. Velta má pví upp hvort í slíkum aðstæðum hefði verið erfitt að fylgja eftir áherslum Aðalnámskrár leikskóla um fjölbreytt leikskólastarf (Mennta- og menningarmálaráðuneytið, 2011) par sem reynt var að mæta styrkleikum hvers barns í takmörkunum sem pessum - pó sérstaklega með tilliti til barna sem njóta sín vel í hreyfingu, til dæmis í sal eða útiveru. Á tímum mikilla breytinga er mikilvægt að sýna börnum skilning og fylgja peim skyldum að hlusta á raddir peirra (lög um samning Sameinuðu pjóðanna um réttindi barnsins nr. 19/2013) svo að hægt sé að koma til móts við fjölbreyttar parfir og áhuga barnanna. Pó mikilvægt sé að vernda börn pá hafa pau hæfni til pess að taka pátt í umræðu og hafa áhrif á líf sitt og daglegt starf í leikskóla, séu pau spurð og á pau hlustað.

Börnin sem tóku pátt í pessari rannsókn höfðu flest gert sér hugmynd um hvað kórónuveiran væri, pau sýndu fram á töluverða pekkingu á veirunni og hvaða takmarkanir hún setti peim. Petta kom fram bæði í máli peirra og teikningum. Börn læra af pátttöku sinni í samfélaginu og eru virk í að móta pað. Pess vegna er mikilvægt að pau fái tækifæri til pess að deila reynslu sinni og upplifunum svo að nýta megi pær til áhrifa (Rogoff, 2003; Rogoff o.fl., 2014). Börnin upplifðu til dæmis takmarkanir vegna sóttvarna með mismunandi hætti. Einni stúlku fannst gott að fá frí frá leikskólanum og vera heima, eins og Elísabet benti á: „Ég mátti vera heima og heima hjá ömmu minni ... pað var skemmtilegt.“ Í nýlegri breskri rannsókn (Pascal o.fl., 2020) kom fram að petta gæti sérstaklega átt við um börn par sem fjárhagur og félagsstaða fjölskyldu er góð. Pessu gæti verið pveröfugt farið pegar um fátækar fjölskyldur og viðkvæma hópa er að ræða. Sumum börnum fannst skemmtilegt í leikskólanum, leið vel pegar öll börnin voru saman og fannst pví leiðinlegt hversu fá börn voru á staðnum. Nokkur börn töluðu um að betra væri að hafa fá börn í leikskólanum af pví að pá væru minni læti. Einnig kom fram í fyrstu niðurstöðum rannsóknar Ingibjargar Óskar Sigurðardóttur og Svövu Bjargar Markar (2020) að leikskólastjórum og leikskólakennurum fannst leikurinn blómstra hjá börnunum pegar pau voru færri í hóp. Pessar niðurstöður gefa til kynna mikilvægi pess að skoða betur aðstæður barna í leikskólum með tilliti til fjölda barna í rýmum en taka parf tillit til viðhorfa barna og peirra 
félagslegu tengsla sem pau hafa myndað við önnur börn og starfsfólk leikskólans.

Rannsóknir hafa sýnt að vinátta og leikur er eitt pað mikilvægasta í augum barna pegar pau eru spurð um pátttöku sína í leikskólastarfi (Jóhanna Einarsdóttir og Sara M. Ólafsdóttir, 2020). Erfiðast var fyrir börnin sem voru pátttakendur í pessari rannsókn að geta ekki verið með vinum sínum. Petta kom fram pegar Snær talaði um að hann saknaði Ólafs, vinar síns, sem ekki var í sama hópi og hann. Hann upplifði sig pví ekki sem fullgildan pátttakanda í barnahópnum (Carr og Lee, 2019; Laevers, 1994) meðan á takmörkunum stóð, eins og hann sagði sjálfur: „En nú er Ólafur heima ... en ég er bara einn með hinum krökkunum, pá verð ég stundum leiður." Sum barnanna voru á peirri skoðun að betra væri að hafa fá börn saman en flest börnin töluðu um að peim hefði ekki liðið vel par sem pau fundu fyrir takmörkunum á félagslegum tengslum, leikefni og leiksvæðum. Rannsóknir hafa sýnt að pessir pættir hafi áhrif á vellíðan barna í leikskóla (Sara M. Ólafsdóttir og Bryndís Garðarsdóttir, 2016). Pví er mikilvægt að taka tillit til vináttu barna pegar skipta parf peim í hópa, ef mögulega er hægt að koma pví við, svo að pau séu örugg, peim finnist pau tilheyra barnahópnum og líði vel í daglegu starfi leikskólans.

Áhugavert var að heyra og sjá hversu skynsamlega börnin töluðu um veiruna og faraldurinn í heild sinni. Í umræðu sinni sýndu börnin skilning á hvernig fólk smitast og veikist. Sum peirra voru uppfull af pekkingu, höfðu lært mikið um takmarkanir, breytta samskiptahætti fólks, útlit og hegðun veirunnar, svo eitthvað sé nefnt. Sú pekking sem kom fram í máli peirra og teikningum bendir til pess að pau hafi byggt pessa pekkingu upp með virkri pátttöku í samfélagi, bæði í leikskóla og með fjölskyldu sinni (Mayall, 2003; Prout og James, 2015). Líta má á slíka pátttöku barnanna sem óbeint nám par sem pau sáu og heyrðu pað sem fram fór í samfélaginu, lögðu sína merkingu í efnið og tóku pátt í að móta samræður og lausnir í tengslum við faraldurinn. Auk pess notuðu börnin ímyndunaraflið, ræddu um og teiknuðu hvernig pau sáu fyrir sér atburði og tengdu við eigin reynslu.

Fram kom að börnin voru stundum óörugg vegna pess að pau voru ekki upplýst um viðveru - eða fjarveru - starfsfólks leikskólans en á sama tíma sýndu pau æðruleysi pegar pau ræddu um aðstæðurnar sem pau bjuggu við í leikskólanum á pessum tíma. Rannsóknir hafa sýnt fram á mikilvægi pess að börn séu upplýst, geti haft áhrif og treyst leikskólakennurum og starfsfólki leikskóla. Áhrifamáttur barna parf að geta stuðlað að öryggi peirra og vellíðan í leikskólasamfélaginu (Byrne og Lundy, 2019; Lansdown, 2005; Moore og McArthur, 2017; Steckermeier, 2019). Niðurstöður pessarar rannsóknar undirstrika mikilvægi pess að tekið sé mið af sjónarmiðum barna og hlustað sé á fjölbreytta tjáningu peirra til pess að öðlast skilning á pví sem er peim mikilvægt. Jafnframt styður petta við styrkleika peirrar rannsóknaraðferðar sem beitt var í pessari rannsókn svo að unnt sé að lesa í tjáningu barnanna og nýta upplýsingarnar til að fá innsýn í skilning peirra og viðhorf.

\section{Lokaord}

Samfélög um heim allan hafa tekist á við COVID-19-faraldurinn á mismunandi vegu. Í sumum löndum var leikskólum lokað svo að börn voru í umsjá fjölskyldna sinna en í ljós hefur komið að aðstæður fjölskyldna eru afar ólíkar og geta peirra til að takast á við aðstæður sömuleiðis. Á Íslandi var tekin sú ákvörðun í fyrstu bylgju faraldursins að halda leikskólum opnum en með ákveðnum takmörkunum. Ef horft er til tímans sem liðinn er frá pví að pessi rannsókn var unnin í fyrstu bylgjunni er áhugavert að skoða ákvarðanatöku stjórnvalda í seinni bylgjunum. Ákveðið var að hafa engar takmarkanir á fjölda barna í leikskólum prátt fyrir hertar aðgerðir og fjöldatakmarkanir á öllu landinu. Eins og rannsóknir hafa sýnt pá smitast börn síður en fullorðnir af kórónuveirunni, veikjast minna og par af leiðandi smita pau síður aðra (Lee og Raszka, 2020). Sú vitneskja er mikilvæg og hefur haft áhrif á ákvarðanatöku stjórnvalda um fyrirkomulag skólahalds. Jafnframt má ekki gleyma að í skólaumhverfinu eru ekki einungis börn, par eru einnig foreldrar peirra, kennarar og annað starfsfólk. Af pessum sökum hefur verið flókið að halda leikskólastarfinu gangandi með sem eðlilegustum hætti par sem meiri hætta er á smiti hjá fullorðnum og peir í meiri hættu á að veikjast alvarlega. Kennarar voru í framlínunni og ekki má gleyma stöðu peirra í faraldrinum par sem peir 
voru í erfiðum aðstæðum, undir miklu álagi og purftu að bregðast hratt við. Pakka má yfirvöldum og sérstaklega leik- og grunnskólakennurum fyrir hversu hratt var brugðist við og lausnir fundnar svo börn gætu sótt leikskóla sinn, allavega í einhverjum mæli. Allir unnu eftir bestu getu í fordæmalausum aðstæðum en mikilvægt er - pegar svona staða kemur upp - að börnin séu fengin með í umræðuna og taki pátt í ákvörðunum er varða pau.

\section{Children's perspectives in times of COVID-19 towards the impact on their participation in preschool}

We are living in an unparalleled time of a pandemic that has affected communities all over the world, and the school system has not been spared. Different measures have been implemented, and in some countries, preschools and primary schools were closed to reduce the spread of the disease and protect the health care system. The closing of schools has affected the education of $80 \%$ of children in the world. In Iceland, the Ministry of Health decided not to close the schools. Instead, restrictions on their operations were imposed. This decision was made because children seemed to be less affected by the virus than did adults. It was considered important to keep the schools open so that children could have access to education and care and maintain their daily routines. The restrictions recommended were for schools to reduce the number of children in groups and to separate groups over a period to lower the risk of infection. In preschools, the groups were separated by allocating days for each group to come to the preschool. Consequently, children were not able to attend the preschool every day. However, exceptions were made for children in vulnerable groups and those whose parents were front-line workers.

The aim of this study is to explore how the children experienced changes made in the preschool during the first wave of the pandemic. The purpose is to learn from the children and use the knowledge created to support children and the planning of the preschool environment in unprecedented times. The research builds on the idea that children are competent persons who construct their knowledge in collaboration with other children and adults. They have the right to be active participants in society and influence their daily lives.

The research was conducted in one preschool in Iceland. Daily, 120 children attend the preschool in six classes. During the restrictions, only half of the children could attend the school. Twenty-three children, aged three to six years, participated in the study. The children took part in group interviews during the period of restrictions and two months later when the restrictions had been reduced. The children were invited to draw during the conversation with the researcher. The discussion was about COVID-19 and how it affected daily practice in the preschool. The conversations with the children were audiorecorded, transcribed, and used for further analysis. Thematic analysis was applied to find key issues and develop themes, searching for an answer to the research question which was: How do the children experience the COVID-19 pandemic and its impact on their participation in daily practice in the preschool?

The main findings of the study appearing in the data, the interviews, and children's drawings revealed the children as having considerable knowledge about the pandemic and its effects on society as well as in daily life in homes and the preschool. Most of the children experienced limitations in their preschool days, such as in their social relations, access to play materials, and the available play areas. The children's views towards the restrictions were diverse. Some children thought it was good to have fewer children in the preschool, as there was less noise than before. Other children expressed a feeling of loneliness within the group of children because of the absence of friends. These children did not want to play, or as Snær put it: "But now Ólafur is at home... and I am just alone 
with the other children, which sometimes makes me sad." What seemed to be the most difficult aspect for the children during the pandemic was not being able to play with their friends. The children's discussion seemed to focus more on the negative effect of the restrictions than the positive. All the children agreed on the COVID-19 time as being boring and one of the participating girls expressed the wish that COVID-19 would vanish. The findings of the study underline the importance of preschool teachers gaining insight into children's views, seeing what is important for children, and supporting and including their perspectives when making plans for the preschool.

According to the Icelandic National Curriculum Guide (Mennta- og menningarmálaráðuneytið, 2011), children should be provided with varied environments where they are able to use their strengths and construct a positive self-image. The findings of this study indicate that in the preschool practice, the points of emphasis in the school curricula could not be fully followed during COVID-19. During the restrictions, the children were mainly located in their classroom and could not always play with friends. Access to play materials was limited as were areas for play and other activities. The results underline the importance of considering children's perspectives and listening to their multiple ways of expressing themselves to be able to support their needs and well-being in the daily preschool practice, both in times of restrictions and all other days.

Keywords: Children's perspectives, children's agency, preschool, preschool practice, COVID-19

\section{Um höfunda}

Sara M. Ólafsdóttir (saraola@hi.is) er lektor í leikskólafræði við Menntavísindasvið Háskóla Íslands. Sara lauk doktorsprófi í menntunarfræði við Háskóla Íslands árið 2019. Megináherslur í rannsóknum hennar hafa verið sjónarmið barna gagnvart hinum ýmsu viðfangsefnum, s.s. leik, páttaskilum milli leik og grunnskóla, vellíðan barna og fullgildi.

Kristín Karlsdóttir (krika@hi.is) er dósent í menntunarfræði ungra barna við Menntavísindasvið Háskóla Íslands. Í kennslu og rannsóknum hefur hún m.a. fengist við pátttöku barna í leik og námi, áhrifamátt barna, lýðræði í leikskólum og skráningu námssagna sem matsaðferð í leikskólastarfi.

Díana Lind Sigurjónsdóttir (dlg3@hi.is) er meistaranemi í leikskólakennarafræðum við Menntavísindasvið Háskóla Îslands. Kjörsvið hennar er nám og kennsla í skóla án aðgreiningarífjölmenningarsa mfélagi. Díana lauk B.Ed.-gráðu íleikskólakennarafræðum við Háskóla Íslands árið 2017. Lokaverkefni hennar var skapandi hópverkefni sem fjallaði um virðingu fyrir kennarastarfinu. Díana starfar sem sérkennari í leikskóla.

\section{About the authors}

Sara Margrét Ólafsdóttir (saraola@hi.is) is an assistant professor at the School of Education, University of Iceland. Sara completed her doctoral study in education in 2019. Her work has emphasised research with children. The topics she has explored with children are, among others: children's play, well-being, belonging and transition from preschool to primary school.

Kristín Karlsdóttir (krika@hi.is) is an associate professor in early education at the School of Education, University of Iceland. Her teaching and research deals with children's participation in play and learning, children's agency, democracy in preschools and the documentation of Learning Stories as an assessment method. 
Díana Lind Sigurjónsdóttir (dlg3@hi.is) is a master's student in preschool teacher education at the School of Education, University of Iceland. Her field of study is inclusive education and teaching in a multicultural society. Díana completed her B.Ed. degree in preschool teacher education in 2017. Her final project was a creative group project that dealt with respect for the teaching profession. Díana works as a special teacher in a preschool.+

\section{Heimildir}

Alderson, P. (2008). Young children's rights: Exploring beliefs, principles and practice (2. Útgáfa). London: Jessica Kingsley Publishers.

Auglýsing um takmörkun á skólastarfi vegna farsóttar nr. 216/2020.

Bae, B. (2009). Children's right to participate: Challenges in everyday interactions. European Early Childhood Education Research Journal, 17(3), 391-406.

Bernstein, B. (2000). Pedagogy, symbolic control and identity: Theory, research, critique (2. útgáfa). London: Rowman and Littlefield Publishers.

Braun, V. og Clarke, V. (2006). Using thematic analysis in psychology. Qualitative Research in Psychology, 3(2), 77-101.

Braun, V. og Clarke, V. (2013). Successful qualitative research: A practical guide for beginners. London: Sage.

Byrne, B. og Lundy, L. (2019). Children's rights-based childhood policy: A six-P framework. The International Journal of Human Rights, 23(3), 357-373. https://doi.org/10.1080/13642987.2018.1558977

Carr, M. og Lee, W. (2019). Learning stories in practice. Los Angeles: Sage.

Dockett, S., Einarsdóttir, J. og Perry, B. (2012). Young children's decisions about research participation: Opting out. International Journal of Early Years Education, 20(3), 244-256. doi:10.1080/09669760.2012.715405

Groundwater-Smith, S., Dockett, S. og Bottrell, D. (2015). Participatory research with children and young people. London: Sage.

Guðrún Kristinsdóttir og Hervör Alma Árnadóttir. (2015). Hliðvörður - hvert er hlutverk pitt? Pátttaka barna í rannsóknum. Netla - Veftímarit um uppeldi og menntun. Sótt af http://netla.hi.is/greinar/2015/ryn/002.pdf

Ingibjörg Ósk Sigurðardóttir og Svava Björg Mörk. (2020). Leikur barna blómstraði á tímum takmarkana á skólahaldi. Sótt af https://bakhjarl.menntamidja.is/2020/09/17/leikur-barna-blomstradi-a-timum-tak markana-a-skolahaldi/?fbclid=IwAR3BLN00okXfOFAHGt6-2bIepXLyQW8bymkPiDwTL5xY2623uP fHQ4gRUmg

Jóhanna Einarsdóttir. (2012). Raddir barna i rannsóknum. Reykjavík: RannUng og Háskólaútgáfan.

Jóhanna Einarsdóttir, Dockett, S. og Perry, B. (2009). Making meaning: Children's perspectives expressed through drawings. Early Child Development and Care, 179(2), 217-232. doi: 10.1080/03004430802666999

Jóhanna Einarsdóttir og Sara M. Ólafsdóttir. (2020). Fullgildi í leikskóla: Sjónarmið barna og starfsfólks. Tímarit um uppeldi og menntun, 29(2), 113-131. doi:10.24270/tuuom.2020.29.6

Karlsson Lohmander, M. og Pramling Samuelsson, I. (2015). Play and learning in early childhood education in Sweden. Psychology in Russia: State of the Art, 8(2), 18-26. doi:10.11621/pir.2015.0202

Laevers, F. (1994). The innovative project: Experimental education and the definition of quality in education. Í F. Laevers (ritstjóri), Defining and assessing quality in early childhood education (bls. 159-172). Leuven, Belgíu: Leuven University Press.

Lancker, W. V. og Parolin, Z. (2020). COVID-19, school closures, and child poverty: A social crisis in the making. The Lancet Public Health, 5(5), 243-244. doi:10.1016/S2468-2667(20)30084-0

Lansdown, G. (2005). Can you hear me? The right of young children to participate in decisions affecting them. Working papers in early childhood development no. 36. Haag, Hollandi: Bernard van Leer Foundation. 
Lee, B. og Raszka, W. V. (2020). COVID-19 transmission and children: The child is not to blame. Pediatrics, 146(2), e2020004879. doi:10.1542/peds.2020-004879

Lög um samning Sameinuðu pjóðanna um réttindi barnsins nr. 19/2013.

MacNaughton, G., Rolfe, S. og Siraj-Blatchford, I. (2010). Doing early childhood research: International perspectives on theory and practice (2. útgáfa). London: Open University Press.

Mayall, B. (2003). Sociologies of childhood and educational thinking. London: Institute of Education.

Mennta- og menningarmálaráðuneytið. (2011). Aðalnámskrá leikskóla 2011. Reykjavík: Höfundur.

Moore, T. og McArthur, M. (2017). 'You feel it in your body': How Australian children and young people think about and experience feeling and being safe. Children and Society, 31(3), 206-218. doi:10.1111/chso.12183

Pascal, C., Bertram, T., Cullinane, C. og Holt-White, E. (2020). COVID-19 and social mobility. Impact Brief\# 4: Early Years. Sótt af https://www.suttontrust.com/wp-content/uploads/2020/06/Early-Years-Impact-Brief.pdf

Prout, A. og James, A. (2015). A new paradigm for the sociology of childhood? Provenance, promise and problems. Í A. James og A. Prout (ritstjórar), Constructing and reconstructing childhood: Contemporary issues in the sociological study of childhood (bls. 6-28). London: Routledge.

Rogoff, B. (2003). The cultural nature of human development. Oxford: OUP.

Rogoff, B., Moore, L. C., Correa-Chávez, M. og Dexter, M. (2014). Children develop cultural repertoires through engaging in everyday routines and practices. Í J. E. Grusec og P. D. Hastings (ritstjórar), Handbook of socialization (bls. 472-484). New York: Guilford Publications.

Sara M. Ólafsdóttir og Bryndís Garðarsdóttir. (2016). Velliððan barna í leikskólastarfi; Samstarfsrannsókn. Í Kristín Karlsdóttir og Anna Magnea Hreinsdóttir (ritstiórar), Leikum, larum, lifum: Námssvið leikskóla og grunnpattir menntunar (bls. 31-56). Reykjavík: RannUng og Háskólaútgáfan.

Steckermeier, L. C. (2019). Better safe than sorry. Does agency moderate the relevance of safety perceptions for the subjective well-being of young children? Child Indicators Research, 12, 29-48. doi:10.1007/s12187 $-017-9519-\mathrm{y}$

Wood, E. (2014). The play-pedagogy interface in contemporary debates. Í L. Brooker, M. Blaise og S. Edwards (ritstjórar), The Sage handbook of play and learning in early childhood (bls. 145-156). London: Sage.

Sara M. Ólafsdóttir, Kristín Karlsdóttir og Díana Lind Sigurjónsdóttir. (2020).

Sýn barna á kórónuveiruna og áhrif hennar á daglegt starf í leikskóla.

Netla - Veftímarit um uppeldi og menntun: Sérrit 2020 - Menntakerfi og heimili á tímum COVID-19

Sótt af http://netla.hi.is/serrit/2020/menntakerfi_heimili_covid19/02.pdf

DOI: https://doi.org/10.24270/serritnetla.2020.23 